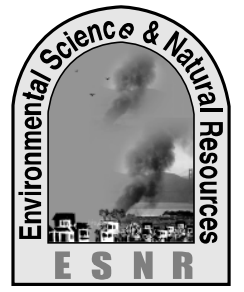

J. Environ. Sci. \& Natural Resources, 6(1): 187 - 193, 2013

ISSN 1999-7361

\title{
Study on Biodiversity Conservation Practice in Madhupur Sal Forest, Bangladesh
}

\author{
A. K. Paul, M. M. Mian, M. B. Khan and M. T. Islam \\ Department of Environmental Science, Bangladesh Agricultural University, Mymensingh \\ ${ }^{1}$ Graduate Training Institute, Bangladesh Agricultural University, Mymensingh
}

\begin{abstract}
The study was conducted in Madhupur Sal Forest, which is very well known for its characteristics as deciduous forest, to describe the diversity of plant species and animal species and to examine the diversity status in Madhupur Sal Forest. A stratified random quadrate method was employed in the study. A total of 40 plant species were recorded of which 21 were tree species, 9 were herbs, 5 were shrubs and rests 5 were climbers. Total 17 animal species were recorded of which 9 were birds, 3 were amphibians, 2 were reptiles and 3 were mammals. With regards to the quantitative attributes of total flora and fauna species, the highest number was found in trees (mean, 14.20) and the lowest number was found in mammals (mean, 0.80). The result showed very high significant variation among them. It was evident from the study that the people around the forest collect forest flora $(75.45 \%)$ and fauna $(8.18 \%)$ illegally is the major cause of biodiversity loss. The people are not aware of the importance of forest in various aspects like social, economical, ecological and environmental aspects. Forest authorities are trying to involve the people in and around the forest in community forestry through motivation and training.
\end{abstract}

Key words: Biodiversity, Conservation, Species Composition, Management, Madhupur Sal Forest

\section{Introduction}

The forest is an important natural resource that plays several important roles in nature and it is a store house of biological diversity. Asia is losing almost $1 \%$ of tropical forest per year. In Asia, some $67 \%$ of wildlife habitat has been converted to other uses (McNeely, 1991). Biodiversity provides essential services including nutrient cycling, air and water purification, flood and drought mitigation, and soil recuperation. It supplies the raw materials for food clothes, housing and medicines. Major industries also rely on past and present biodiversity resources. These services can't always be measured in terms of money alone (WRI, 2002). The direct economic benefits of biodiversity run into trillions of dollars per year (Constanza et al., 1997). Madhupur Sal forest, which is also known as Madhupur Garh (garh meaning 'fort'), comprises an area of 45,565 acres, of which 2,525 acres are reserved forest though gazette notification, and the remaining 43,039 acres are in the process of being declared as reserved forests. A total of 44,533 acres have been surveyed (Dey, 2007).

The main forest tree species in Madhupur Sal forest is Sal (Shorea rubusta). Formerly the area was very rich in flora and fauna and had populations of elephants and different sub-species of Indian tigers, bears, and birds. Most of these mammals are now locally extinct. Remaining fauna species include monkeys, deer, and languor. Floral species include haldu, korai, satain, ronia, kadam, dewa, neem, shimul, etc. (Rahman et al., 2007).Until the beginning of the 20th century, Sal forests existed as a large continuous belt with rich biological resources, but increasing pressure has been placed on them due to the ever-increasing population. Most of the forest area at present is under occupation by encroachers and the remaining stands are stocked poorly (Islam, 2003). Bearing the above situation in mind, a study on biodiversity and conservation practice of the Madhupur Sal Forest was conducted to find quantitative attributes of flora and fauna of Madhupur Garh, Structural composition of that flora and fauna and management of the Madhupur Sal Forest.

\section{Methodology}

\section{Study duration}

The study was conducted from 7 June 2012 to 10 December 2012.

\section{Study area}

The study area comprise of Sal forest is situated in the Madhupur Upazila (Sub-district) of Tangail district. The forest extends between $23^{\circ} 50^{\prime}-24^{\circ} 50^{\prime} \mathrm{N}$ and $89^{\circ} 54^{\prime}-90^{\circ} 50^{\prime} \mathrm{E}$ (Nishatet al. 2002) covering an area of 24150.02 ha which are honeycombed with habitation and agricultural land comprising four ranges namely Madhupur, Sronkhola, Dokhola arid, Madhupur National Park Sadar.

\section{Study of vegetation composition and structure}

Quadrat method was used for counting plant and animal's species of the study area. In total of 5 quadrats, each of $30 \mathrm{ft} \times 30 \mathrm{ft}$ dimension were selected randomly. In each quadrate, the number of various rooted plant species and wild animal species were recorded. The birds were observed either through binocular or by naked eyes. Notes were taken on different ecological and ethological aspects. Field data were used to calculate frequency, relative frequency, density, relative density, relative 
dominance, abundance and importance value index following the method of Zobelet al. 1987. (a) Frequency (\%): This term refers to the degree of dispersion of individual species in an area and usually expressed in terms of percentage. It is calculated by the equation:

$$
\text { Frequency }(\%)=\frac{\text { Number of quadrate in which the species }}{\text { Total nuber of quadrates studied }} \times 100
$$

(b) Relative Frequency (\%): The degree of dispersion of individual species in an area in relation to the number of all the species occurred.

$$
\text { Relative frequency }(\%)=\frac{\text { Number of the species }}{\text { Number of all species }} \times 100
$$

(c) Density: Density is an expression of the numerical strength of a species where the total number of individuals of each species in all the quadrats is divided by the total number of quadrats studied. Density is calculated by the equation:

$$
\text { Density }=\frac{\text { Total number of individual of a species in all quadrats }}{\text { Total number of quadrate stidied }}
$$

(d) Relative Density (\%): Relative density is the study of numerical strength of a species in relation to the total number of individuals of all the species and can be calculated as:

$$
\text { Relative density }(\%)=\frac{\text { Number of individual of the species }}{\text { Number of individual of all the species }} \times 100
$$

(e) Relative Dominance (\%): Dominance of a species is determined by the value of the basal cover. Relative dominance is the coverage value of a species with respect to the sum of coverage of the rest of the species in the area.

$$
\text { Relative dominance }(\%)=\frac{\text { Number of basal area of the specific species }}{\text { Total basal area of all the species }} \times 100
$$

(f) Abundance: It is the study of the number of individuals of different species in the community per unit area. By quadrats method, samplings are made at random at several places and the number of individuals of each species was summed up for all the quadrats divided by the total number of quadrats in which the species occurred. It is represented by the equation:

$$
\text { Abundance }=\frac{\text { Total number of individual s of a species in all quadrats }}{\text { Total number of quadrats in which the species occured }}
$$

(g) Importance Value Index: This index is used to determine the overall importance of each species in the community structure. In calculating this index, the percentage values of the relative frequency, relative density and relative dominance are summed up together and this value is designated as the Importance Value Index or IVI of the species.

Importance value Index = (relative density + relative dominance + relative frequency $)$

\section{Data Collection on conservation and management}

The data was collected from both primary and secondary sources. A pre-tested structural questionnaire was used to collect primary data.
Secondary data were mostly collected from research publications. 


\section{Key informant Interview (KII)}

Some key informant interview was conducted with various stake holders which people were expert and associated with forest conservation and management. For study purposes interview was carried out with Divisional Forest Officer (DFO), conservator of forest (ACF) and Bit Ranger. Respondent selected by a random selection from study areas to collect local view. 3 Focus Group Discussion (FGD) was taken at Dokhola Bazar, Beribaid tea stall and Sadar bit range tea stall, to addressing overall people view about Sal Forest. It also technically collected answer of research question through FGD.

\section{Data processing and Analysis}

All the data both spatial and especial collected from different sources has been tabulated and analyzed separately. The spatial data has been analyzed using statistical computer software like; Mstatc, Microsoft Excel, and SPSS etc. Finally all the analyzed data have been integrated and presented as maps, tables and graph and interpret and discussed in results and discussion.

\section{Results and discussion}

\section{Study of the species composition and structure}

The results of the present study on quadrate methods for various species of flora and fauna were recorded, tabulated and finally analyzed for their (i) attributed and (ii) structural characters.

\section{Quantitative attributes of the Survey result of total flora and fauna}

A total of 8 types of flora and fauna (4 types of flora and 4 types of fauna) were found in 5 quadrate of Madhupur Sal forest. Among the floral species, 21 species of trees under 10 families, 9 species of herbs under 9 families, 5 species of shrubs under 5 families and 5 species of climbers under 4 families were identified. Among faunal species, 9 species of birds under 7 families, 3 species of amphibians under 3 families, 2 species of reptiles belonging to 2 families and 3 species of mammals belonging to 2 families were identified. The highest number was trees (mean, 14.20) followed by herbs (mean, 8.60). The lowest number was found in mammals (mean, 0.80) preceded by reptiles (mean, 1.0) (Table 1). The results showed very high significant variation among them. There was no statistically significant variation among shrubs, climbers and birds and amphibians, reptiles and mammals.

Table1: Means of analysis of variance for quantitative attributes of total flora and fauna obtained through quadrates $(30 \mathrm{ft} \times 30 \mathrm{ft})$ survey at Madhupur Garh

\begin{tabular}{|l|l|l|}
\hline \multirow{4}{*}{ Flora } & Plant types & Mean number found \\
\cline { 2 - 3 } & Herbs & $8.6 \mathrm{~b}$ \\
\cline { 2 - 3 } & Shrubs & $4.2 \mathrm{c}$ \\
\cline { 2 - 3 } & Trees & $14.20 \mathrm{a}$ \\
\cline { 2 - 3 } & Climbers & $4.2 \mathrm{c}$ \\
\hline \multirow{4}{*}{ Fauna } & Animal types & \\
\cline { 2 - 3 } & Amphibians & $2.2 \mathrm{~d}$ \\
\cline { 2 - 3 } & Reptiles & $1.0 \mathrm{~d}$ \\
\cline { 2 - 3 } & Birds & $4.6 \mathrm{c}$ \\
\cline { 2 - 3 } & Mammals & $0.8 \mathrm{~d}$ \\
\hline Level of Significant & $\mathbf{0 . 0 1 \%}$ \\
\hline
\end{tabular}

\section{Structural composition of the studied flora and} fauna

At first the flora and fauna found in the studied area were identified on local names and the scientific names were given later. Then analyzed and computed the frequency, relative frequency, density, relative density, relative dominance, abundance and important value index (IVI). Results are presents in Table 2 and discussed below. Regarding tree species, the highest density was calculated in Sal/Garjan (25.8) followed by Sheora (19.2) and Sinduri (12.8). On the other hand, lowest density was showed by Jam (1.2) proceeded by Amloki (1.4). Again, the highest frequency was represented by Sal/Garjan, Bohera, Sinduri, and Jarul (100\%). The lowest frequency was represented by Amloki, Sisu, jam, and Eucalyptus (20\%). Moreover, highest abundance was found in Sal/Garjan (25.8) followed by Sheora (24.0) and Sisu (17.0). The lowest abundance was calculated in Bot (2.5) proceeded by Ulatkambal (2.66) and Arboroi (3.0). Furthermore, the highest relative density was calculated in Sal/Garjan (19.97\%) followed by Sheora (14.86\%) and Sinduri (12.8\%). The lowest relative density was found in Jam (0.93\%) Proceeded by Amloki (1.084\%). 
Table 2: Analysis of quantitative structure of tree, Herb, Shrub and Climber species in the study area

\begin{tabular}{|c|c|c|c|c|c|c|c|c|c|}
\hline $\begin{array}{l}\dot{z} \\
\dot{m}\end{array}$ & 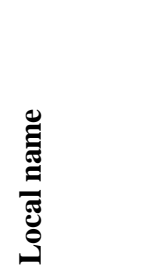 & 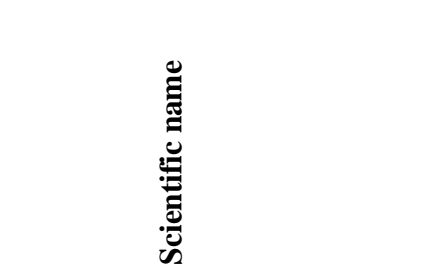 & 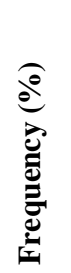 & 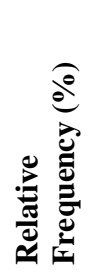 & 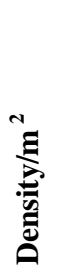 & 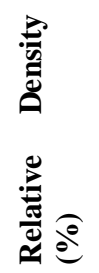 & 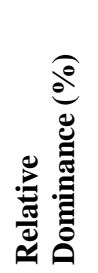 & 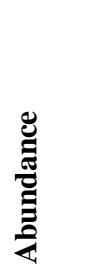 & 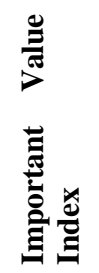 \\
\hline 1 & $\mathrm{Am}$ & Mangiferaindica $L$ & 60 & 4.23 & 4.8 & 3.72 & 60 & 8.0 & 0.68 \\
\hline 2 & Amrah & Spondiaspinnata (L.f.) Kerz & 40 & 2.82 & 3.8 & 2.94 & 40 & 9.5 & 0.46 \\
\hline 3 & Bohera & TerminaliabelericaRoxb & 100 & 7.04 & 3.6 & 2.79 & 100 & 3.6 & 1.098 \\
\hline 4 & Amloki & Phyllanthusembelica $L$. & 20 & 1.41 & 1.4 & 1.084 & 20 & 7.0 & 0.225 \\
\hline 5 & Sinduri & MallotusphillippensisMuell. Arg. & 100 & 7.04 & 12.8 & 9.91 & 100 & 12.8 & 1.170 \\
\hline 6 & Arboroi & Phyllanthusacidus $(L)$ Skiels & 80 & 5.63 & 2.4 & 1.86 & 80 & 3.0 & 0.875 \\
\hline 7 & Kanchan & Bauhinia acuminata $L$. & 80 & 5.63 & 10.8 & 8.4 & 80 & 13.5 & 0.939 \\
\hline 8 & Lohakat & XyliadolabiformisBenth & 80 & 5.63 & 2.8 & 2.17 & 80 & 3.5 & 0.878 \\
\hline 9 & Sisu & DalbergiasissooRoxb. & 20 & 1.41 & 3.4 & 2.632 & 20 & 17.0 & 0.240 \\
\hline 10 & Jarul & Lagerstroemia speciasa (L.) Pers & 100 & 7.04 & 5.6 & 4.33 & 100 & 5.6 & 1.113 \\
\hline 11 & Asathwa & Ficusreligiosa $L$. & 80 & 5.63 & 3.2 & 2.84 & 80 & 4.0 & 0.881 \\
\hline 12 & Pia & Toonaciliata J. Roem & 80 & 5.63 & 5.6 & 4.33 & 80 & 7.0 & 0.899 \\
\hline 13 & Sheora & Streblusasper (Lour.) & 80 & 5.63 & 19.2 & 14.86 & 80 & 24.0 & 1.00 \\
\hline 14 & Sal & ShorearobustaGaertn & 100 & 7.04 & 25.8 & 19.97 & 100 & 25.8 & 1.270 \\
\hline 15 & Bot & Ficusbengalensis L. & 80 & 5.63 & 2.0 & 1.548 & 80 & 2.5 & 0.872 \\
\hline 16 & Gamari & Gmelinaarborea L. & 60 & 4.23 & 2.0 & 1.548 & 60 & 3.33 & 0.63 \\
\hline 17 & Ulatkambal & Abromaaugusta L. & 60 & 4.23 & 1.6 & 1.24 & 60 & 2.66 & 0.65 \\
\hline 18 & Chapalish & ArtocarpuschaplashaRoxb. & 80 & 5.63 & 2.8 & 2.167 & 80 & 3.5 & 0.878 \\
\hline 19 & Shidah & Lagerstroemia parvifloraRoxb. & 80 & 5.63 & 11.8 & 9.133 & 80 & 14.75 & 1.148 \\
\hline 20 & Jam & Syzygiumgrandis (Wt.) Wall. & 20 & 1.41 & 1.2 & 0.93 & 20 & 6.0 & 0.223 \\
\hline 21 & Eucalyptus & Eucalyptus comaldulensis & 20 & 1.41 & 2.4 & 1.86 & 20 & 12 & 0.233 \\
\hline$\overline{22}$ & Ban ghagra & Urenalobata $L$. & 80 & 12.12 & 14.6 & 20.87 & 80 & 18.25 & 1.13 \\
\hline 23 & Thankuni & Centelllaasiatico (L.) Urban & 100 & 15.15 & 12.0 & 17.14 & 100 & 12.0 & 1.327 \\
\hline 24 & Bhant & Clerodendrumviscosumvent & 100 & 15.15 & 19.6 & 28.0 & 100 & 19.6 & 1.43 \\
\hline 25 & Apang & Achyranthesaspera $L$. & 60 & 9.09 & 3.2 & 4.57 & 60 & 5.33 & 0.735 \\
\hline 26 & Kukursinga & Blumealacera (Burm. F.) DC. & 60 & 9.03 & 1.4 & 2.00 & 60 & 2.33 & 0.711 \\
\hline 27 & Keumul & $\begin{array}{l}\text { Costusspeciosus (Koen. EX Retz.) } \\
\text { Smith }\end{array}$ & 60 & 9.03 & 4.8 & 6.86 & 60 & 8.0 & 0.7594 \\
\hline 28 & Kalomegh & AndrogrophispaniculataNees & 60 & 9.03 & 4.0 & 5.714 & 60 & 6.66 & 0.7479 \\
\hline 29 & Assar, & Grewiamicrocos $L$ & 80 & 12.12 & 9.0 & 12.85 & 80 & 11.25 & 1.0497 \\
\hline 30 & Hurhuria & Cleome viscose $L$ & 60 & 9.03 & 1.4 & 2.00 & 60 & 2.33 & 0.711 \\
\hline 31 & Bashok & AdhatodavasicaNees & 80 & 19.05 & 13.6 & 31.34 & 80 & 17.0 & 1.304 \\
\hline 32 & Akanda & Calotropisgigontea $\mathrm{Br}$. & 100 & 23.81 & 9.2 & 21.19 & 80 & 9.2 & 1.45 \\
\hline 33 & Arhar & Cajanuscajan (L.) Millsp. & 60 & 14.29 & 1.2 & 2.76 & 60 & 2.0 & 0.77 \\
\hline 34 & Dhutura & Daturametel L. & 100 & 23.80 & 8.8 & 20.28 & 100 & 8.8 & 1.44 \\
\hline 35 & Kutushkta & Lantana camara L Var. & 80 & 19.05 & 10.6 & 24.42 & 80 & 13.25 & 1.23 \\
\hline 36 & Assam lata & Mikaniascandens & 100 & 23.80 & 9.4 & 16.55 & 100 & 9.4 & 1.404 \\
\hline 37 & Kumarilata & Smilax zeylanica $L$. & 80 & 19.05 & 2.6 & 4.58 & 80 & 3.25 & 1.04 \\
\hline 38 & Amallata & Vitistrifolia $L$. & 80 & 19.05 & 4.6 & 8.1 & 80 & 5.75 & 1.07 \\
\hline 39 & Harjora & Vitisquadrangularis Wall. & 80 & 19.05 & 4.6 & 8.1 & 80 & 5.75 & 1.07 \\
\hline 40 & Bet & CalamusrotungWilld. & 80 & 19.05 & 33.8 & 59.50 & 80 & 42.25 & 1.585 \\
\hline
\end{tabular}

The highest relative frequency were represented by Sal/Garjan, BoheraSinduri, Jarul (7.04\%) while the lowest was measured in Amloki, Sisu, Jam, Eucalyptus (1.41\%). Species with the highest relative dominance were found in Sal/Garjan, Bohera, Sinduri, Jarul $(100 \%)$. The result depicted that
Amloki, Sisu, jam, Eucalyptus were the lowest relative dominance $(20 \%)$ in the studied area. The importance value index (IVI) studied showed highest IVI in Sal followed by Sinduri and the lowest IVI was found in Amloki preceded by Sisu. Following tree species the highest and lowest frequency, 
abundance, relative density, relative frequency and the importance value index (IVI) of Herbs, Shrubs and Climbers were represented on (Table 2). On Table 2, Sl No. 1-21 represent trees, 22-30 represent herbs, 31-35 represent shrubs and 36-40 represents climbers species. The structural composition of bird species and their analysis result is presented in Table 3. Among the birds species, highest density was measured in Salik (3.8) followed by Doel (2.0). On the contrary, lowest density was calculated in Tia (0.2). Again, the highest frequency was found in Salik $(80 \%)$ While the lowest frequency found in Tia (20\%). Moreover, highest abundance was measured in Salik (4.75) followed by Doel (3.3) while the lowest abundance was found in Kotrepecha, Kokil, Kak thokra and Tia, each of them present (1.0). The highest relative density was found in Salik (35.84\%) followed by Doel (18.86\%). The lowest relative density was found in Tia $(1.89 \%)$. The highest relative frequency was calculated in Salik (17.39\%) while the lowest relative frequency was measured in Tia (4.34\%). Species with the highest relative dominance was calculated in Salik $(80 \%)$ while the lowest relative dominance was calculated in Tia $(20 \%)$. The importance value index (IVI) studied showed highest IVI in Salik (1.33) followed by Doel (0.92) and the lowest IVI was found in Tia (0.26). Following bird species the highest and lowest frequency, abundance, relative density, relative frequency and the importance value index (IVI) of amphibians, reptiles and mammals were represented on (Table 3). In Table 3, Si No. 1-9 represents birds, 10-12 represent amphibians, 13-14 represent reptiles and 15-17 represent mammal's species.

Table 3: Analysis of quantitative structure of bird, amphibian, reptile and mammal species in the study area

\begin{tabular}{|c|c|c|c|c|c|c|c|c|c|}
\hline $\begin{array}{l}\dot{0} \\
\dot{Z}\end{array}$ & 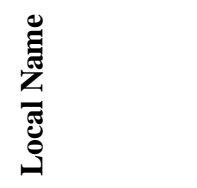 & 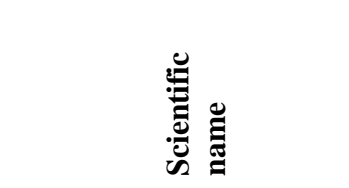 & 矛 & 总 & 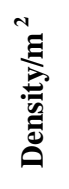 & 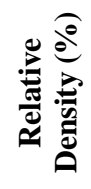 & 冚导 & 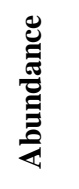 & 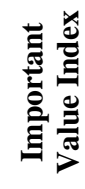 \\
\hline 1 & Salik & Acridotherestristis & 80 & 17.39 & 3.8 & 35.84 & 80 & 4.75 & 1.33 \\
\hline 2 & $\begin{array}{l}\text { Red-vented } \\
\text { bulbul }\end{array}$ & Pycnonotuscafer & 60 & 13.04 & 1.4 & 13.21 & 60 & 2.33 & 0.89 \\
\hline 3 & Kotrepecha & Athenebrama & 40 & 8.7 & 0.4 & 3.77 & 40 & 1.0 & 0.52 \\
\hline 4 & Koel/Kakil & Eudynamysscolopacea & 40 & 8.7 & 0.4 & 3.77 & 40 & 1.0 & 0.52 \\
\hline 5 & Tailor bird & Orthotomussutorius & 60 & 13.04 & 1.2 & 11.32 & 60 & 2.0 & 0.84 \\
\hline 6 & Doel & Copsychussaularis & 60 & 13.04 & 2.0 & 18.86 & 60 & 3.33 & 0.92 \\
\hline 7 & Shama & Copsychusmalabaricus & 60 & 13.04 & 0.8 & 7.547 & 60 & 1.33 & 0.81 \\
\hline 8 & Kath thokra & Microptermusbrachyurus & 40 & 8.7 & 0.4 & 3.77 & 40 & 1.0 & 0.52 \\
\hline 9 & Tia & Psittaculakrameri & 20 & 4.34 & 0.2 & 1.89 & 20 & 1.0 & 0.26 \\
\hline 10 & Kuno bang & Bufome!anostictus & 80 & 36.36 & 1.4 & 43.75 & 80 & 1.75 & 1.602 \\
\hline 11 & Gecho bang & Rhacophorusleocomystax & 80 & 36.36 & 1.0 & 31.25 & 80 & 1.25 & 1.48 \\
\hline 12 & Kula bang & Ranatigrina & 60 & 27.27 & 0.8 & 25.0 & 60 & 1.33 & 1.123 \\
\hline 13 & Guishap & Varanusbengalensis & 0.6 & 60 & 1.0 & 60.0 & 60.0 & 60.0 & 1.8 \\
\hline 14 & Garden lizard & Calotesversicolor & 0.4 & 40 & 1.0 & 40.0 & 40.0 & 40.0 & 1.2 \\
\hline 15 & $\begin{array}{l}\text { Mukhpora } \\
\text { Hanuman }\end{array}$ & Trachypithecuspileatus & 20 & 33.33 & 0.4 & 16.66 & 20 & 2.0 & 0.70 \\
\hline 16 & Banor & Macacamulatta & 20 & 33.33 & 1.4 & 58.33 & 20 & 7.0 & 1.12 \\
\hline 17 & Deer & Axis axis & 20 & 33.33 & 0.6 & 25.0 & 20 & 3.0 & 0.78 \\
\hline
\end{tabular}

\section{Management of the Madhupur Sal Forest}

\section{Respondents' perception on forest resource extraction}

110 respondents were selected randomly at study area. Out of 110 respondents, there were $27.27 \%$ farmer, $18.18 \%$ day labor, $31.82 \%$ house wives, $9.10 \%$ service holder and unemployment about $13.64 \%$ which are shown in Table 4. From survey result it is found that $74.54 \%$ people in study area collect forest flora for different purposes. Most of them collect forest flora due to wood trade, fuel wood, and household furniture and for medicinal value of plants. The collection of flora and fauna lead to decrease the biodiversity in the forest. The highest forest flora were collected by unemployed people $(93.33 \%)$ due to demand of money and often involved in illegal wood trade. 
Table 4: Illegal collection of forest flora and fauna for different purposes

\begin{tabular}{|c|c|c|c|c|c|c|c|c|c|c|}
\hline \multirow{3}{*}{ 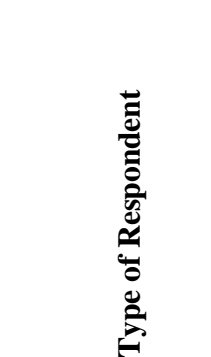 } & \multirow{3}{*}{ 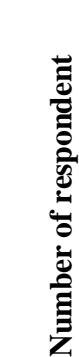 } & \multirow{3}{*}{ 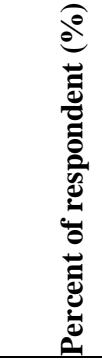 } & \multicolumn{2}{|c|}{$\begin{array}{l}\text { Opinion about } \\
\text { collection of } \\
\text { flora }\end{array}$} & \multicolumn{2}{|c|}{$\begin{array}{l}\text { Opinion about } \\
\text { collection of } \\
\text { fauna }\end{array}$} & \multicolumn{2}{|c|}{$\begin{array}{l}\text { Opinion about } \\
\text { collection of flora }\end{array}$} & \multicolumn{2}{|c|}{$\begin{array}{l}\text { Opinion about } \\
\text { collection of fauna }\end{array}$} \\
\hline & & & \multicolumn{2}{|l|}{ Yes } & \multicolumn{2}{|l|}{ Yes } & \multicolumn{2}{|l|}{$\mathrm{NO}$} & \multicolumn{2}{|l|}{ NO } \\
\hline & & & 离 & $\%$ & $\frac{\bar{d}}{\bar{E}}$ & $\%$ & 离 & $\%$ & $\frac{\bar{\Xi}}{\grave{B}}$ & $\%$ \\
\hline Farmer & 30 & 27.27 & 25 & 83.33 & 2 & 6.66 & 5 & 16.67 & 28 & 93.33 \\
\hline Day labor & 20 & 18.18 & 17 & 85.0 & 1 & 5.0 & 3 & 15.0 & 19 & 95.0 \\
\hline House Wives & 35 & 31.82 & 26 & 74.29 & 0 & 0.0 & 9 & 25.71 & 35 & 100.0 \\
\hline Service Holder & 10 & 9.10 & 1 & 10.00 & 0 & 0.0 & 9 & 90.00 & 10 & 100.0 \\
\hline Unemployment & 15 & 13.64 & 14 & 93.33 & 6 & 40.0 & 1 & 6.66 & 9 & 60.0 \\
\hline Total & 110 & 100.0 & 83 & 75.45 & 9 & 8.18 & 27 & 24.55 & 101 & 91.82 \\
\hline
\end{tabular}

Respondent's perceptions about solution of the Problems

The survey result of respondent's opinion about problem solution regarding with present management system and biodiversity conservation were presented in Table 5Most of the respondents ( $37.27 \%$ ) said that the awareness activities should be carried out to make aware the people the importance of biodiversity, forest area for social, ecological and environmental situation of human life and it was $37.27 \%$. About $26.36 \%$ respondents stated that considering local dependence on the forest resources, sustainable use of some resources like vegetables, honey, medicinal plants and other non timber forest products may be allowed (Table 6). Some respondents said that the illegal clear felling and collection of forest flora and fauna should be stopped.

Table 5: Respondents opinion about the problem solution ( $\mathrm{N}=110)$

\begin{tabular}{|l|c|c|}
\hline Nature of solution & $\begin{array}{l}\text { Number of } \\
\text { respondent }\end{array}$ & $\begin{array}{l}\text { Present } \\
(\%)\end{array}$ \\
\hline $\begin{array}{l}\text { Forest management should be modernized through forest master plans, acts and } \\
\text { policies to include local participation, preventing the illegal consumption of forest } \\
\text { products. }\end{array}$ & 7 & 6.36 \\
\hline 2. Improvement and extension of existing wildlife breeding centers essential. & 3 & 2.78 \\
\hline $\begin{array}{l}\text { 3. } \\
\text { Awareness activities should be carried out to make the people understand the } \\
\text { importance of biodiversity, forest area in social, economical, ecological and } \\
\text { environmental situation of human life. }\end{array}$ & 41 & 37.27 \\
\hline $4 . \quad$ Clear felling should be stopped by any means to conserve the forest biodiversity. & 18 & 16.36 \\
\hline $5 . \quad \begin{array}{l}\text { Short-rotational plantations with exotic trees should gradually be replaced with } \\
\text { indigenous species for social forestry. }\end{array}$ & 12 & 10.91 \\
\hline $\begin{array}{l}\text { Considering local dependence on the forest resources, sustainable use of some } \\
\text { resources like vegetables, honey, medicinal plants and other non timber forest products } \\
\text { may be allowed. }\end{array}$ & 29 & 26.36 \\
\hline \begin{tabular}{l} 
Total \\
\hline
\end{tabular} & 110 & 100.0 \\
\hline
\end{tabular}

\section{Conclusion}

The structural composition of flora found in Madhupur Garh were, among tree species the highest density was calculated in Shal/Garjan $\left(25.8 / \mathrm{m}^{2}\right)$,The highest frequency of tree species was represented by Shal/Garjan, Bohera, Sinduri, and Jarul (100\%) and the lowest frequency was represented by Amloki, Sisu, jam, and Eucalyptus (20\%). The structural composition of fauna found in Madhupur Garh were, among bird species the highest frequency was found in Shalik (80\%) While the lowest frequency found in Tia (20\%). Concerning amphibian species, the highest frequency was found in Kuno bang and Gecho bang, each of them present $(80 \%)$ while the lowest frequency found in Kula bang $(60 \%)$. The study showed that the people around the forest collect forest flora (75.45\%) and fauna (8.18\%) illegally. About flora they collected large trees like Shal, Jarul, sheora for various purposes. In fauna they collected different birds like Tia, Red turtle dove/ 
lalghugu, koel etc. because of their demand in local market. The people are not aware of the importance of forest in various aspects like social, economical, ecological and environmental aspects. Forest authorities are trying to involve the people in and around the forest in community forestry through motivation and training. The study also indicated that the major causes of biodiversity loss were illegal wood trading and pouching. Large amount diversity was lost due to agricultural activities and fuel wood collection. The major problems from administrative point of views that the Madhupur Garh is not $100 \%$ reserve forest and 52 families illegally residing and occupying illegally 400 acres of land. Many other minor problems also associated with administration. The study revealed that the biodiversity in the Madhupur Sal forest is decreasing day by day.

\section{References}

Constanza, R.; Arge, R.; de Groot, R.; Fabes, S.; Grano, M.; Hannon, B.; Limburg, K.; Naeem, S.; O’Neil, R. V.; Pareulo, J.; Raskin, R.; Sulton, P. and Vander Belt, M.1997. The value of world's ecosystem services and natural capital. Nature, 387: $254-260$

Dey, S.; 2007. The commercialization of the indigenous economy and its impact on the environment of Modhupur Garh, Bangladesh, Int. J. Green Economics, Vol. 1, Nos. 3/4, pp.465-477.
Islam, S. S. 2003. State of forest genetic resources conservation and management in Bangladesh. Forest Genetic Resources Working Papers, Working Paper FGR/68E. Forest Resources Development Service, Forest Resources Division. FAO, Rome, pp 31.

McNeely, J. A. 1991. Forest biodiversity at the ecosystem level: where do people fit in? Unasylva.Special issue on Forest Biological Diversity, 53(2): pp 10-15.

Nishat, A.; Huq; Imanul, S. M.; Barua; Shuvashish, P.; Ali, R.; Khan, A. H. M.; Moniruzzaman, A. S. 2002. Bio-ecological zones of Bangladesh. IUCN Bangladesh Country Office, Dhaka, Bangladesh, xii + 141pp.

Rahman, M. M.; Vacik H.; Begum, F.; Nishad, A.; Islam, K. K. 2007.Comparison of structural diversity of tree-crop associations in Peripheral and Buffer zones of Gachabari Sal forest area, Bangladesh. Journal of Forestry Research, 18(1): 23-26.

WRI, 2002. Why Care about Ecosystems? (http:/www.wri.org/wr2000/why_care.html) WWF and IUCN 1994-1995. Centres of Plant Diversity.A guide and strategy for their conservation.3 Volumes. IUCN Publications Unit,Cambridge.http:/www.wri.org/wr2000/ why_care.html, 2002

Zobel, D. B.; Yadav, U. K.; Jha, P. K. and Behan, M. J. A. 1987. practical manual for ecology. Rani Printing Press, Kathmandu, Nepal. 